\title{
ICT Utilization in Science Teachers of Underdevelopment Region
}

\author{
Saefuddin ${ }^{1 *}$, Saleh ${ }^{2}$, Fahyuddin ${ }^{3}$ iD \\ ${ }^{1,2,3}$ Department of Chemistry Education University of Halu Oleo, Kendari, Indonesia
}

*Corresponding author: saefuddin@uho.ac.id

\begin{abstract}
Research has been carried out to examine the use and mastery of ICT for science teachers in underdeveloped areas. This study aims to: obtain valid data regarding teachers' ICT knowledge and skills; knowing the extent to which the teacher implements ICT knowledge and skills in the classroom; identify the factors faced by teachers in implementing ICT in learning; to determine support and effective ICT development strategies to be applied to teachers. The research method is a survey, practical test, and statistical validation. It found that male teachers, young teachers, honorary teachers, and secondary school teachers tended to have higher ICT competence. It was found that the ICT applications that have been used by more than $50 \%$ of teachers are word processing, presentation processing, internet, and document navigation. The analysis results show that only about $2 \%$ of teachers stated that ICTs had little effect on their learning in the classroom and that training on how to do this had the most positive impact on teachers. It can be concluded that professional training on ICT needs to be effectively and sustainably provide; continuing to improve ICT infrastructure in schools will positively impact the use of ICT by teachers; teachers' overall attitude is very positive for self-development.
\end{abstract}

Keywords: Usage ICT, Underdevelopment Region, Science

\begin{tabular}{|c|c|c|}
\hline History: & & Publisher: Undiksha Press \\
\hline Received & : April 05, 2021 & Licensed: This work is licensed under \\
\hline Revised & : April 07, 2021 & a Creative Commons Attribution 3.0 License \\
\hline Accepted & : June 20, 2021 & (c) (†) () \\
\hline Published & : July 25, 2021 & (C) ${ }_{B Y} S_{S A}$ \\
\hline
\end{tabular}

\section{INTRODUCTION}

ICTs should be used in various conditions, including schools in $3 \mathrm{~T}$ areas. The region and schools' condition in the 3T area, teachers, facilities, and learning resources are lacking. With ICT, these deficiencies can be minimized (Koesnandar, 2013; Warsihna, 2014). One of the underdeveloped areas that need special attention in ICT is Konawe Kepulauan Regency (Southeast Sulawesi). In conventional learning, science teachers usually use pictures and props to provide an overview for students when the lesson is in progress. However, with the development of technology, of course, the existence of more modern media can be used by teachers to facilitate the teaching and learning process (Lawless \& Pellegrino, 2007; Wang et al., 2019; Yanuarti \& Rusman, 2018). Along with technological development, ICT devices can also be used to support science learning in schools. UNESCO in the Information and Communication Technology in Education: A Curriculum for Schools and Program of Teacher Development (UNESCO) module mentions two models in implementing ICT integrated learning: The Continuum Approach and the Learning Phase Approach using ICT. Each model includes stages that must be met by schools and teachers in implementing ICT integrated learning. One of the efforts to accelerate education quality improvement is by utilizing ICT (Hew \& Brush, 2007; Jaffer et al., 2007; Koesnandar, 2013; Yanuarti \& Rusman, 2018). Almost nonsense talks about improving quality, the quality of the learning process, teacher competence, learning resources, and various learning innovations without using ICT.

In addition, various efforts have been made to improve the quality of Indonesia's human resources, which are not only taken through the implementation of compulsory 
education programs (Luthfiah \& Kusumawati, 2012). Other efforts include improving the curriculum, increasing the education budget, providing facilities, and educational infrastructure, professional development of teaching staff (teachers), student exchanges, and the provision of information technology facilities in order to adapt to scientific developments with other countries (Barrett et al., 2019; Skobeltsina \& Kuznetsov, 2019). The development of information technology allows a country to follow other countries' progress without being limited by the dimensions of space and time. Information that occurs outside a country can be known in seconds without going to the source of information. The development and advancement of the world of information technology can be used in various life fields, including education. The development of education in a country can easily be accessed through internet facilities. Educational issues, research results, and various other findings can be obtained easily through this facility.

Therefore, it is essential to know the competence of human resources, especially science teachers, in Konawe Kepulauan Regency's disadvantaged areas, especially regarding their ability to use information technology in their learning activities. Science teacher respondents were chosen because, in this science lesson, there were subjects whose learning media were widely available on the internet, such as laboratory experiments, demonstrations of the use of suitable tools/materials, and examples of natural changes that occurred in the surrounding environment. So far, there has been no research that reports data on this capability in a comprehensive manner. This study expected to provide information about the constraints faced by teachers, especially in disadvantaged areas.

\section{METHODS}

This research is descriptive survey research whose scope and focus are a sample survey. The research sample is taken from the total population of science teachers in each disadvantaged district and surveyed at a particular time (cross-sectional survey). The research data was obtained by filling out survey questionnaires, interviews, and technical tests on computers and the internet to science teachers and the school as stakeholders. Using a descriptive survey research design, noting that it can generate data from external factors on a problem as investigated in this study. Therefore, through this method, researchers can interact with teachers who are considered for the investigation and can extract the necessary information from them to interpret teacher constraints in using ICT in teaching in Kabuten Konawe Islands.

This study's population was all science teachers of elementary school, Junior high school, and Senior high school/ Vocational high schools from the Konawe Kepulauan Regency. Simultaneously, the research sample was randomly selected from each Unit Pelaksana Tekniks Diknas, each with ten teachers from each school level in each district. So there were ten science teachers involved in this study. The research instrument used a questionnaire - the questionnaire entitled: Constraints in the use of ICT for science teachers in disadvantaged areas. The questionnaire was designed to seek information and opinions from teachers about the constraints of science teachers in using ICT in teaching at Elementary School, Junior High School, and Senior High School/Vocational High School in Konawe Kepulauan Regency. The items developed in the questionnaire are used to generate appropriate data to answer the research questions posed and the hypotheses formulated for the study. Participants' responses based on a four-point Likert scale - strongly agree (4), agree (3), disagree (2) and strongly disagree (1). 


\section{RESULTS AND DISCUSSION}

\section{Results}

\section{Demographic Factors}

Data from various aspects regarding teachers that have been questioned in this survey include demographics, school ICT capacity, professional training that teachers participate in, teacher-controlled computer applications, school planning and leadership regarding the use of ICT in, teacher attitudes towards ICT, and the use of ICT in the room class. The demographic condition of teachers in Konawe Kepulauan Regency is shown in Table 1. Statistically, the table's demographic factors have a significant relationship with the scores of teachers' ICT skills obtained through technical tests. Male teachers, young teachers (25 - 49 years), honorary teachers, and middle school teachers tend to have higher ICT competence. Meanwhile, demographic factors that do not significantly affect teachers' ICT abilities are teachers with additional duties as admin, subjects managed by the teacher, working mode/hours, length of work as teachers, and school location (far / near the district capital).

Table 1. Teacher demographic data

\begin{tabular}{lc}
\hline Teacher Sample & $\begin{array}{c}\text { Konawe Kepulauan } \\
\text { Regency }\end{array}$ \\
\hline Gender & 12 \\
\hline Male & 18 \\
Female & \\
\hline What age group are you in? & 0 \\
\hline Less than 24 years & 5 \\
25 to 29 years & 18 \\
30 to 39 years & 7 \\
40 to 49 years & 0 \\
50 to 64 years & 0 \\
Over 65 years & \\
\hline Employment status & 21 \\
\hline Permanent employees (PNS) & 0 \\
Permanent Employee (Foundation) & 9 \\
Temporary employees (honorary) & 0 \\
Internship & \\
\hline The level of the school where it teaches & 17 \\
\hline Elementary School & 5 \\
Junior High School & 8 \\
Senior High School/ Vocational High School & \\
\hline
\end{tabular}

Table 1 shows the said categories of productive age dominate the demographic distribution of teachers in the age group of 30-39 years of age. At the age of 30-39, teachers can still be trained to use ICT in learning. In addition, the skills and dexterity chosen by the teacher were still at the usual threshold level compared to teachers who were 40 years and over. Besides, the use of ICT is dominated by gender factors, namely men and women. Gender affects the social presence of the internet, perceived ease of use of the internet, and perceptions of the internet's benefits (Rahmawaty, 2017; Vilia, 2017). The perception of women about the social existence of the internet is higher than that of men. Women also perceive the internet's benefits higher than men, but men tend to use the internet more easily than women. Meanwhile, from the results of the investigation, it was found that the main inhibiting factor for respondents not to use the internet was due to being busy. It can also be 
supported by the types of work heavily involved in domestic work, caused by the unfair distribution of gender roles for women. Other inhibiting factors are slow connections, cluelessness (technologically illiterate), and lack of time (Najih, 2017).

\section{Mastered Computer Applications}

Some of the applications commonly used by teachers and their level of mastery are shown in Table 2, and it is found that the ICT applications that have been used and mastered by an average of more than $50 \%$ of teachers are word processing, presentation processing, spreadsheet, email, internet, and document navigation.

Table 2. Applications used by teachers and their level of mastery

\begin{tabular}{lc}
\hline & $\%$ \\
\cline { 2 - 2 } Applications that can be used by the Teacher & $\begin{array}{c}\text { Konawe Kepulauan } \\
\text { Regency }\end{array}$ \\
\hline Word processor & 73 \\
Presentation & 48 \\
Microsoft Excel & 47 \\
Internet & 49 \\
E-mail & 43 \\
Document navigation (Windows explorer) & 56 \\
Microsoft Access & 17 \\
\hline
\end{tabular}

Word processing is the most popular application and controlled by more than $70 \%$ of teachers in the three districts, although teachers still have never used the application. In detail, word processing mastery is shown graph in Figure 1. Using columns and sections, spell check, and page style settings are the skills in this application with the lowest mastery level, 56\%, 60\%, and 60\%, respectively, all by teachers from Konawe Kepulauan Regency. Based on Table 2, it can be seen that the highest percentage comes from the word processing aspect, which consists of using the column section, opening existing documents as shown in Figure 1. The word processing aspect contributed $73 \%$ of the total participants in all aspects analyzed in the computer application section that mattered.

Table 2 and Figure 1 show the availability of ICT services, their use, and their uses in the Konawe Kepulauan Regency. Technological assistance, be it hardware or software, is something to keep in mind in this section. No technician was assigned directly to assist in this. Typically, these instructors serve as technicians for themselves or their co-workers. Infrastructure, technological infrastructure, and other factors are inadequate to prevent ICT use in the learning system, especially during the learning process (Chisango \& Lesame, 2019). Meanwhile, cultivating teachers' understanding of technology, promoting technology adoption, and then teaching to improve teacher digital literacy and technical, pedagogical material skills is one way to close the gap between uses. Assume that encourage technology introduction and offer instruction to help teachers improve digital literacy and pedagogical and scientific material skills. As a result, benefit programs, such as ICT-based teaching units, are open to all leadership approaches, creating more ways to inspire the forms of ICT inclusion needed in education (Wang et al., 2019; H. H. Yang et al., 2018; N. Yang \& Yang, 2019).

\section{The capacity of existing ICT in schools, the use and accessibility}

The availability of ICT facilities, their use, and accessibility in Konawe Selatan District are shown in Table 3. What should be noted in this section is technical support, both 
regarding hardware and software. No technicians are specifically tasking to provide such support; usually, the teachers also act as technicians for themselves or their colleagues.

Table 3. ICT capacity, usage, and accessibility

\begin{tabular}{lccc}
\hline \multirow{2}{*}{ Capacity ICT in the School } & \multicolumn{3}{c}{$\%$} \\
\cline { 2 - 4 } & Availability & Usage & Ease of Access \\
\hline Technical support & 29 & 28 & 27 \\
PC / laptop computer for own use & 79 & 73 & 71 \\
Notebook / laptop for teaching use & 54 & 51 & 50 \\
Individual email accounts & 80 & 73 & 73 \\
Printer & 87 & 79 & 79 \\
Digital camera & 36 & 29 & 30 \\
Digital projector (LCD) & 66 & 49 & 53 \\
In-class computer for student use & 4 & 4 & 4 \\
Computer in another room (library / lab.) & 37 & 34 & 36 \\
For student use & & & \\
\hline
\end{tabular}

\section{Professional Training}

Computer training attended mainly by teachers was basic computers and word processing, while the least attended was database training (Table 4). From all the training has been followed, the science teachers from schools in these districts assume that the basic computer training provided the most benefit for science teachers.

Table 4. ICT professional training attended by teachers

\begin{tabular}{lccc}
\hline & \multicolumn{3}{c}{$\%$} \\
\cline { 2 - 4 } Type of Training & Followed & $\begin{array}{c}\text { Regulated by } \\
\text { the School }\end{array}$ & Effective? \\
\hline $\begin{array}{l}\text { Basic computer training (how to use a } \\
\text { computer) }\end{array}$ & 30 & 13 & 24 \\
$\begin{array}{l}\text { Computer user training for student } \\
\text { information systems and curriculum }\end{array}$ & 14 & 11 & 13 \\
management & 28 & 16 & 21 \\
Word processing training & 21 & 13 & 18 \\
$\begin{array}{l}\text { Excel training } \\
\text { PowerPoint training }\end{array}$ & 28 & 16 & 21 \\
$\begin{array}{l}\text { Access (Database) Training } \\
\text { Training on how to integrate technology }\end{array}$ & 9 & 6 & 6 \\
into the curriculum & 17 & 12 & 17 \\
\hline
\end{tabular}

The most common computer training forms for teachers were main computers and word processors, while the training database was the least popular (Table 4). The science teachers in this district believe that basic computer training is the most beneficial of all the training that has been made. The UNESCO Study on ICT Competency Systems for Teachers is a valuable guide for educating students, politicians, and professional learning institutions about the role of ICTs in education. Various forms of teaching, especially for science teachers in underprivileged communities, help achieve this. In a review of the use of ICTs in learning in South Africa, although schools and educators value the advantages of ICT in 
learning and are willing to apply technology, various factors hinder the adoption of ICT in the teaching and learning process, including professionalism in the use of ICTs, capabilities, and usability (Chigona et al., 2010).

\section{The use of ICT in the classroom}

Figure 2 illustrates teachers' responses from Konawe Kepulauan District to what extent they use ICT in their teaching practices and how well they are performing. ICTs have a big impact on what students do and how they learn. According to $53 \%$ of teachers, $21 \%$ believe that ICT can improve students' ability to learn, and only $2 \%$ believe that ICT has little impact on student learning. However, almost $22 \%$ of teachers say that they lack the potential to use ICT in class (Figure 2).

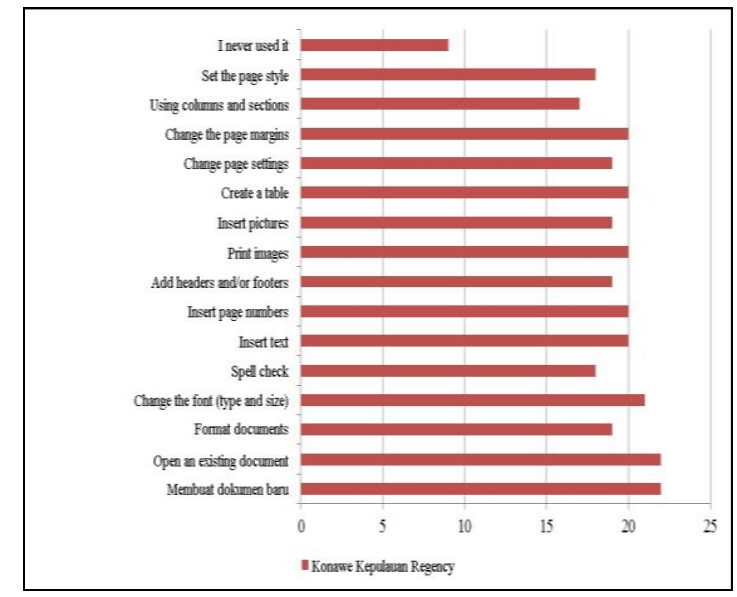

Figure 1. Mastery of word processing for science teachers in Konawe Kepulauan Regency

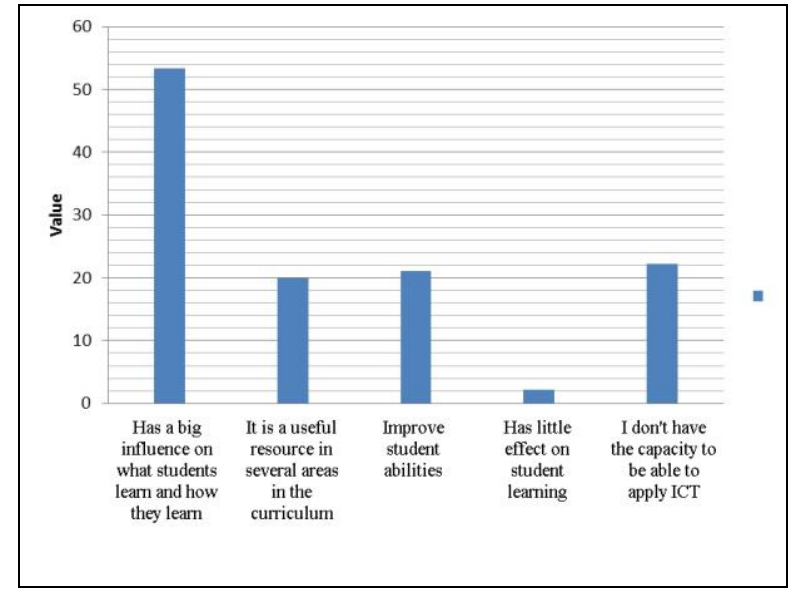

Figure 2. Implementation of ICT in the classroom

Based on Figure 2 shows that most teachers have used technology, according to research findings (Figure 2). As a result, the teachers' powerful computers and smartphones to create PowerPoint displays for a regular teaching and learning experience. A more effective technology solution must be given to students (Li \& Walsh, 2011). The teacher must be prepared to use various elements such as pictures, sound, and film in a power-point presentation. For example, a power-point demonstration does not resemble a board presentation. The use of ICT in the learning system makes learning more enjoyable, comfortable, and enjoyable for teachers and students, motivates students, makes learning more enjoyable, improves the presentation of material, and allows greater access to computers (Dawes, 2012). For personal use, giving teachers more power in the school, giving teachers more prestige, and making administration more effective. ICT also refers to the use of various technology tools and services and related metadata to collaborate, generate, disseminate, archive, maintain, and retrieve data (Francis et al., 2017). Meanwhile, increasing student education standards and increasing teachers' competence in disadvantaged areas in ICT use in education requires a different focus.

\section{Discussion}

In many countries, education investors needed ICT to enhance educational outcomes and teaching and learning quality (Jaffer et al., 2007; Mirzajani et al., 2016). Even if this inadequacy is unlikely to be due to a lack of adequate educational technologies, acknowledging that technology and the internet are here to stay is inadequate to change 
literacy teaching in many schools (Margolis et al., 2017; Trotter, 2007). Computers are not being used as effectively as they should be (Wells \& Lewis, 2006). It's important to note that educators must still develop new techniques and knowledge activities (Asad et al., 2020; Dolan, 2016; Karchmer et al., 2005). According to research, not all educators are well-versed in the benefits of ICT and how to apply them in the classroom (Bingimlas, 2009; Gil-Flores et al., 2017; Hew \& Brush, 2007). Some teachers may be enthusiastic about incorporating technology into the school, but they cannot do so due to a lack of self-efficacy.

In research involving 390 students, despite virtually all of them being adequately ICT qualified, few teachers used ICT in the classroom; some even used higher levels of ICT competence in their personal lives (Rene'Moses, 2006). In a survey of 11 school educators, only around a fifth of them regularly used ICT in the classroom (Rakes et al., 2006). The factors that affected teachers' innovative ICT use (Drent \& Meelissen, 2008). According to their findings, a learner-centered pedagogical approach, programming experience, an optimistic attitude toward computers, and the teacher's entrepreneurship all influenced the educator's creative use of ICT. Previous study looked at how Turkish VET school educators use educational technology (Mumcu, 2010). According to their findings, educators mostly used ICT for administrative purposes, with no use for actual educational purposes. Other previous study found that older teachers were more likely to use teaching resources regularly than new teachers (Lau \& Sim, 2008). Since they have both teaching experience and basic knowledge of ICT, more senior teachers could easily integrate instructional technology into their classroom practice. Teachers could support and integrate ICT into their classrooms if teacher training plans often focused on ICT skills and innovative classroom activities (Lawless \& Pellegrino, 2007). Trainee teachers should have ample time to acquire enough exposure to pique their curiosity in using ICT. ICT encompasses computer hardware, software, and telecommunications systems (Khan et al., 2012).

Consequently, it refers to a wide variety of computing devices, ranging from pocket calculators to supercomputers. It includes all panel and projection devices for viewing computer output. It refers to both local and wide-area networks that enable computers and people to communicate with one another. These include digital cameras, video games, CDs, DVDs, smartphones, telecommunication satellites, and fiber optics. Included are computerized computers and computerized robots. Therefore, to successfully integrate computers into the classroom, teachers must feel empowered and relaxed using computers regularly for instructional activities. To help their students and promote successful learning, teachers must realize the importance of computing in education. As a result, transforming teachers' pessimistic views towards computers is critical to improving their computing skills. As a result, if teachers wish to use technology effectively in their classrooms, they must have a constructive outlook.

\section{CONCLUSION}

Professional training on ICT needs to be effectively and sustainably provided both in quantity and quality. Continuing to improve technical support for ICT infrastructure in schools will positively impact the use of ICT by teachers. The overall attitude of teachers is very positive for self-development in terms of mastery of ICT. Therefore, to successfully integrate computers into the classroom, teachers must feel empowered and relaxed using computers regularly for instructional activities. To help their students and promote successful learning, teachers must realize the importance of computing in education. As a result, transforming teachers' pessimistic views towards computers is critical to improving their computing skills. As a result, if teachers wish to use technology effectively in their classrooms, they must have a constructive outlook. 


\section{ACKNOWLEDGMENTS}

The authors would like to thank Halu Oleo University for the grants provided to complete research on time.

\section{REFERENCES}

Asad, M. M., Hussain, N., Wadho, M., Khand, Z. H., \& Churi, P. P. (2020). Integration of elearning technologies for interactive teaching and learning process: an empirical study on higher education institutes of Pakistan. Journal of Applied Research in Higher Education, 4. https://doi.org/10.1108/jarhe-04-2020-0103.

Barrett, P., Treves, A., Shmis, T., Ambasz, D., \& Ustinova, M. (2019). The impact of school infrastructure on learning: A synthesis of the evidence. The World Bank. https://doi.org/10.1596/978-1-4648-1378-8.

Bingimlas, K. A. (2009). Barriers to the successful integration of ICT in teaching and learning environments: A review of the literature. Eurasia Journal of Mathematics, Science and Technology Education, 5(3), 235-245. https://doi.org/10.12973/ejmste/75275.

Chigona, A., Chigona, W., Kausa, M., \& Kayongo, P. (2010). An empirical survey on the domestication of ICT in schools in disadvantaged communities in South Africa. International Journal of Education and Development Using ICT, 6(2), 21-32. https://www.learntechlib.org/p/42332/.

Chisango, G., \& Lesame, C. (2019). Exploring accessibility to information and communication technology (ICT) at disadvantaged secondary schools in Gauteng province-South Africa. EDULEARN19 Proceedings 11th International Conference on Education and New Learning Technologies Palma, Spain. 1-3 July 2019, 507-512. https://doi.org/10.21125/edulearn.2019.0178.

Dawes, L. (2012). What stops teachers from using new technology? Issues in Teaching Using ICT , 61-80. https://doi.org/10.4324/9780203185117-5.

Dolan, J. E. (2016). Splicing the divide: A review of research on the evolving digital divide among K-12 students. Journal of Research on Technology in Education, 48(1), 1637. https://doi.org/10.1080/15391523.2015.1103147.

Drent, M., \& Meelissen, M. (2008). Which factors obstruct or stimulate teacher educators to use ICT innovatively? Computers \& Education, 51(1), 187-199. https://doi.org/10.1016/j.compedu.2007.05.001.

Francis, N. N., Ngugi, M., \& Kinzi, J. (2017). Influence of selected factors on the implementation of information and communication technology policy in public secondary schools in Naivasha Sub-County, Kenya. International Journal of Education and Development Using Information and Communication Technology, 13(2), 70-86. https://eric.ed.gov/?id=EJ1153319.

Gil-Flores, J., Rodríguez-Santero, J., \& Torres-Gordillo, J. J. (2017). Factors that explain the use of ICT in secondary-education classrooms: The role of teacher characteristics and school infrastructure. Computers in Human Behavior, 68, 441-449. https://doi.org/10.1016/j.chb.2016.11.057.

Hew, K. F., \& Brush, T. (2007). Integrating technology into K-12 teaching and learning: Current knowledge gaps and recommendations for future research. Educational Technology Research and Development, 55(3), 223-252. https://doi.org/10.1007/s11423-006-9022-5.

Jaffer, S., Ng'ambi, D., \& Czerniewicz, L. (2007). The role of ICTs in higher education in South Africa: One strategy for addressing teaching and learning challenges. International Journal of Education and Development Using ICT, 3(4), 131-142. 
https://www.learntechlib.org/p/42220/.

Karchmer, R. A., Mallette, M. H., Kara-Soteriou, J., \& Leu Jr, D. J. (2005). Innovative Approaches to Literacy Education: Using the Internet to Support New Literacies. International Reading Association.

Khan, M., Hossain, S., Hasan, M., \& Clement, C. K. (2012). Barriers to the introduction of ICT into education in developing countries: The example of Bangladesh. Online Submission, 5(2), 61-80. https://dergipark.org.tr/en/download/article-file/59739.

Koesnandar, A. (2013). Pengembangan model pendayagunaan teknologi informasi dan komunikasi (TIK) untuk pendidikan di daerah terpencil, tertinggal, dan terdepan. Kwangsan: Jurnal Teknologi Pendidikan, 1(2), 122-125. https://doi.org/10.31800/jtp.kw.v1n2.p122--142.

Lau, B. T., \& Sim, C. H. (2008). Exploring the extent of ICT adoption among secondary school teachers in Malaysia. International Journal of Computing and ICT Research, 2(2), 19-36. https://citeseerx.ist.psu.edu/viewdoc/download?doi=10.1.1.372.5339\&rep=rep1\&type $=$ pdf.

Lawless, K. A., \& Pellegrino, J. W. (2007). Professional development in integrating technology into teaching and learning: Knowns, unknowns, and ways to pursue better questions and answers. Review of Educational Research, 77(4), 575-614. https://doi.org/10.3102/0034654307309921.

Li, L., \& Walsh, S. (2011). Technology uptake in Chinese EFL classes. Language Teaching Research, 15(1), 99-125. https://doi.org/10.1177/1362168810383347.

Luthfiah, S., \& Kusumawati, I. (2012). Analisis gerakan penuntasan wajib belajar 9 tahun dalam meningkatkan kualitas SDM. Academy of Education Journal, 3(2). https://doi.org/10.47200/aoej.v3i2.86.

Margolis, J., Estrella, R., Goode, J., Holme, J. J., \& Nao, K. (2017). Stuck in the shallow end: Education, race, and computing. MIT Press.

Mirzajani, H., Mahmud, R., Ayub, A. F. M., \& Wong, S. L. (2016). Teachers' acceptance of ICT and its integration in the classroom. Quality Assurance in Education, 24(2), 2640. https://doi.org/10.1108/qae-06-2014-0025.

Mumcu, K. (2010). ICT in Vocational and Technical Schools: Teachers' Instructional, Managerial and Personal Use Matters. Turkish Online Journal of Educational Technology-TOJET, 9(1), 98-106. https://eric.ed.gov/?id=EJ875772.

Najih, M. A. (2017). Gender dan kemajuan teknologi: pemberdayaan perempuan pendidikan dan keluarga. Jurnal Harkat: Media Komunikasi Gender, 13(1), 18-26. https://doi.org/10.15408/harkat.v13i1.7712.

Rahmawaty, A. (2017). Perempuan dan pemanfaatan teknologi internet dengan pendekatan UTAUT. Palastren Jurnal Studi Gender, 9(1), 13-42. https://doi.org/10.21043/palastren.v9i1.1746.

Rakes, G. C., Fields, V. S., \& Cox, K. E. (2006). The influence of teachers' technology use on instructional practices. Journal of Research on Technology in Education, 38(4), 409-424. https://doi.org/10.1080/15391523.2006.10782467.

Rene'Moses, R. (2006). Factors related to technology implementation of $K-12$ principals and teachers. University of North Texas.

Skobeltsina, K., \& Kuznetsov, A. (2019). Research on public satisfaction with an educational infrastructure of advanced development territories. International Conference on the Development of Education in Eurasia (ICDEE 2019), 36-41.

Trotter, A. (2007). Getting up to speed. Education Week, 26(3), 10-12.

Vilia, B. (2017). Pemanfaatan media internet oleh petani perempuan pedesaan. Studi Pustaka, 1(2), 1-5. http://kpm.ipb.ac.id/karyailmiah/index.php/studipustaka/article/view/4852. 
Wang, J., Tigelaar, D. E., \& Admiraal, W. (2019). Connecting rural schools to quality education: Rural teachers' use of digital educational resources. Computers in Human Behavior, 101, 68-76. https://doi.org/10.1016/j.chb.2019.07.009.

Warsihna, J. W. J. (2014). Pemanfaatan teknologi informasi dan komunikasi (tik) untuk pendidikan daerah terpencil, tertinggal dan terdepan (3T). Jurnal Teknodik, 17(2), 235-245. https://doi.org/10.32550/teknodik.v0i0.82.

Wells, J., \& Lewis, L. (2006). Internet Access in US Public Schools and Classrooms US Department of Education. National Center for Education Statistics.

Yang, H. H., Zhu, S., \& MacLeod, J. (2018). Promoting education equity in rural and underdeveloped areas: Cases on computer-supported collaborative teaching in China. Eurasia Journal of Mathematics, Science and Technology Education, 14(6), 23932405. https://doi.org/10.29333/ejmste/89841.

Yang, N., \& Yang, H. H. (2019). Understanding rural and urban teachers' ICT usage in china: an ecological perspective. 2019 International Joint Conference on Information, Media and Engineering (IJCIME), 498-501. https://doi.org/10.1109/ijcime49369.2019.00106.

Yanuarti, R., \& Rusman, R. (2018). Pemanfaatan teknologi informasi dan komunikasi (TIK) oleh guru di sekolah penerima Universal Service Obligation (USO). Jurnal Penelitian Ilmu Pendidikan, 11(2), 69-83. https://doi.org/10.21831/jpipfip.v11i2.19441. 